\author{
Ekaterina Vasilenko (iD) https://orcid.org/0000-0002-2552-5714 \\ Mogilev State A. Kuleshov University \\ e-mail: e.n.vasilenko@gmail.com
}

\title{
Sexist hate speech: Topical organization of intolerant discourse
}

\begin{abstract}
The article is aimed at determining the topical structure of sexist hate speech as form of intolerant discourse. Sexist hate speech is viewed as a type of gender-based hate speech that is influenced by the same social, political and legal, cultural and ethical factors as sexual orientation-based or gender identity-based hate speech. The article proposes a topical structure of hate speech in general and provides the examples of verbalization of sexist hate speech topics and subtopics in the Belarusian online discourse.
\end{abstract}

Keywords: hate speech, sexist hate speech, gender-based hate speech, discourse of hate, intolerant discourse, online discourse, topic.

\section{Introduction}

Hostility and hate speech take different forms in different discourse communities depending on the local conditions. Over the last couple of decades, a large amount of research has been conducted by European scholars on xenophobic hate speech (Assimakopoulos, 2017) and American scholars on racist hate speech (Moon, 2000).

This article explores the verbalization of hostility within the Belarusian discourse community. The article examines sexist hate speech as a form of intolerant discourse. The study is based on the analysis of Internet users' comments to online news related to women and published on the most popular Belarusian information portal TUT.BY in 2017-2019.

Given that the cultural logic of using the term hate speech is best derived from the analysis of its actual representations in a community (Boromisza-Habashi, 2013), I start 
the article with a brief description of the key terms and an outline of the extralinguistic factors influencing the functioning of gender-based hate speech in general and sexist hate speech in particular within the Belarusian discourse community. I then propose a topical structure of hate speech as form of intolerant discourse and illustrate it with the examples from the Belarusian online discourse.

\section{Sexist hate speech as research object}

Due to the undiminished interest of researchers and policymakers all over the world in hate speech, the term itself has become understood in a very broad sense including any forms of expression, promotion or justification of hostility based on a set of group characteristics (e.g., ECRI, 2016: 3), meanwhile the component speech of the term predetermines its mainly linguistic character.

I argue that hate speech should be considered primarily from the standpoint of language science as a set of language means expressing negative, based on stereotypes and/or prejudices, attitudes towards the addressee as a carrier of values different from those of the addresser and, as a result, verbalizing one or another type of discrimination or intolerance.

At the same time the fact that hate speech is based on stereotypes and/or prejudices makes it necessary to take into account the characteristics of hostility as a social phenomenon. This leads us to the discursive dimension of the research, i.e. to the study of intolerant discourse. (Hereafter, I also use the term discourse of hate as widely accepted though I believe that the words hostility and intolerance - not hate - are more appropriate in the given context as hate is a more acute form of a similar condition, while the consideration of the mild forms of its expression is also essential).

It must be underlined that the described phenomena are very complex and, in some cases, difficult to differentiate. It is necessary in a linguistic analysis to take into account the totality of paralinguistic and extralinguistic factors. Hate speech can target different protected characteristics of a person or group such as religion, race, origin, age, etc., which makes it possible to speak about different kinds of hate speech - religion-based, racist, ethnic-based, ageist, and so on.

I adhere to a wide definition of gender. It is understood as a as a combination of such components as the category of sex, gender identity, marriage and reproductive gender status, sexual orientation, gender processes, gender beliefs and gender display (Шакирова/Shakirova, 2000: 15-26). This interpretation allows for gender-based hate speech to be used as an umbrella term for all the kinds of hate speech based on such characteristics as sex, sexual orientation and gender identity. Therefore, it is possible to single out two vulnerable social groups suffering from gender-based hate speech - women and LGBT people (the term $L G B T$ is used since it is the most widespread, but here it encompasses other forms of sexuality and gender identification). The study focuses on sexist hate speech. 


\section{Sexist hate speech in Belarus}

As sexist hate speech is part of gender-based hate speech, I believe that its functioning in a discourse community is more or less determined by the same social, political and legal, and cultural and ethical factors as the use of sexual orientation-based or gender identity-based hate speech.

In the Belarusian context, social factors determining the functioning of gender-based hate speech are those connected to the change in the socio-cultural paradigm, intensive development of Internet communication technologies, increased social mobility horizontally and vertically and weak civil society (for a more detailed description of social and other factors influencing gender-based hate speech functioning in Belarus see: Vasilenko, 2019).

Political and legal factors include the lack of legal sanctions against the use of hate speech (the only basis on which the Belarusian legislation prohibits discrimination in the context of the given problem is the basis of sex; such notions as gender, gender identity and sexual orientation are not found in legal documents - see: Vasilenko, 2020) and the attitude of the authorities towards gender discrimination and discriminatory statements.

In addition, cultural and ethical factors impact on gender-based hate speech. Homophobic - to a greater extent - and sexist - to a lesser - moods in Belarusian society, the formation and maintenance of gender stereotypes, the active exploitation of discriminatory topics by the media (often the Russian ones which are very popular among the Belarusian population) and the lack of awareness of the majority of the academic community in the field of gender issues all have an influence.

All these factors are deeply interconnected and mutually defining. It is obvious, though, that the list presented is not exhaustive as the use of hate speech is to a great extent dependent of individual (e.g., psychological) and contextual (e.g., communication framework) factors. However, it helps us to understand the general extralinguistic context of gender-based hate speech functioning in the given discourse community.

The study is based on an analysis of Belarusian Internet users' comments to online news related to women and published on the most popular - according to the Information and Analytical Centre of the Administration of the President of the Republic of Belarus (Республика/Respublika, 2018: 15) - Belarusian information portal TUT.BY from $01 / 01 / 2017$ to $31 / 07 / 2019$. The titles of the selected articles contained the words «женщина» 'woman', «феминизм» 'feminism' and «сексизм» 'sexism'.

The analysis of the comments revealed the relatively high degree of importance of gender issues for the Belarusian discourse community (see: Table 1; cf. the readers' response rate to the articles on women, LGBT and foreigners for the same period: 110.7, 245.4 and 90.2 comments on average per article respectively). 
Table 1. TUT.BY users' response to the articles related to women (01/012017-31/07/2019)

\begin{tabular}{|c|c|c|c|}
\hline Key word in the title & Number of articles & Number of comments & $\begin{array}{l}\text { Average number of } \\
\text { comments per article }\end{array}$ \\
\hline \multicolumn{4}{|c|}{$01 / 01 / 2017-31 / 12 / 2017$} \\
\hline Woman & 512 & 51373 & 100.3 \\
\hline Feminism & 6 & 2081 & 346.8 \\
\hline Sexism & 1 & 311 & 311.0 \\
\hline Total 2017 & 519 & 53765 & 103.6 \\
\hline \multicolumn{4}{|c|}{$01 / 01 / 2018-31 / 12 / 2018$} \\
\hline Woman & 583 & 66615 & 114.3 \\
\hline Feminism & 4 & 777 & 194.3 \\
\hline Sexism & 2 & 78 & 39.0 \\
\hline Total 2018 & 589 & 67470 & 114.6 \\
\hline \multicolumn{4}{|c|}{$01 / 01 / 2019-31 / 07 / 2019$} \\
\hline Woman & 323 & 25655 & 79.4 \\
\hline Feminism & 1 & 132 & 132.0 \\
\hline Sexism & 3 & 92 & 30.7 \\
\hline Total 2019 & 327 & 25879 & 79.1 \\
\hline Total & 1435 & 147114 & 110.7 \\
\hline
\end{tabular}

Such an analysis allows us not only to reveal the degree of importance of the problem for each particular discourse community and identify the most salient issues in public life - but also to track the dynamics of the readers' interest over a certain period (see: Figure 1). Here, of the three variables, feminism is the most important.

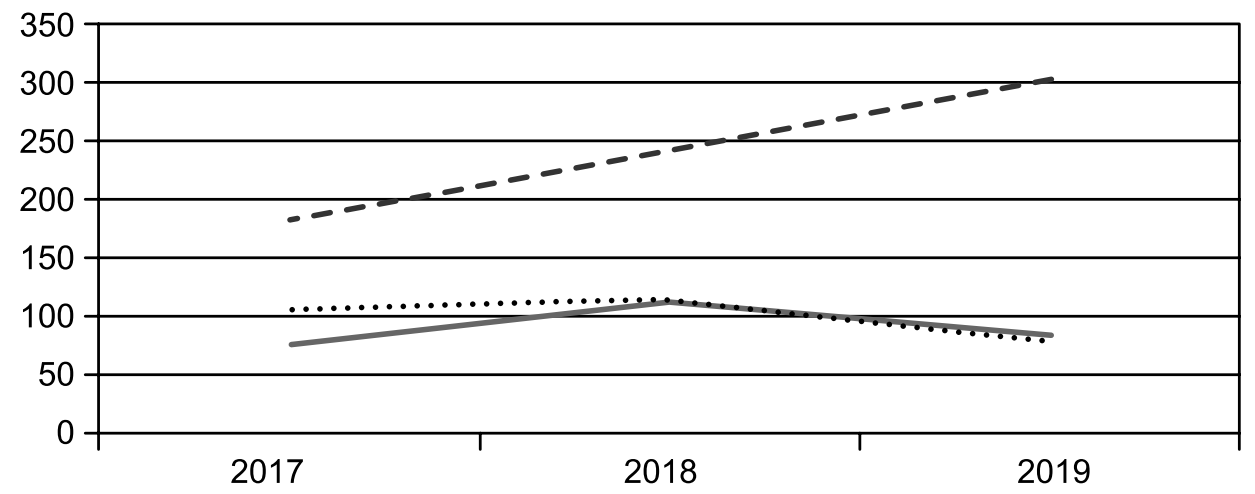

- - LGBT people $\quad . .$. Women $\quad$ Foreigners

Figure 1. Dynamics of TUT.BY users' response to the articles related to women as compared to the articles on LGBT people and foreigners (01/012017-31/07/2019) 


\section{General topical structure of intolerant discourse}

The analysis of intolerant discourse just like any other kind of discourse cannot be carried out without a study of its thematic structure, as topics or themes play a crucial role in the production and comprehension of discourse organizing its local meanings and, therefore, defining its overall coherence (Dijk, 1987: 48).

Given that the discourse of hate is based on stereotypes being one of the types of social attitudes that are widely used by a person in evaluating others (Куницына, Казаринова, Погольша/Kunitsyna, Kazarinova, Pogol'sha, 2001: 330), it seems logical to present a schematic organization of the revealed topics in the form of propositions expressing value judgments.

The importance of presenting topics in the form of propositions is also due to the fact that value judgments belong to the category of cognitive processes, which is relevant in view of the sociocognitive approach to discourse used in the study. The specificity of value judgments lies in the fact that they complete the process of the informative preparation of an action and serve as the basis for and influence directly the so-called regulatory processes: decision making, goal setting and behaviour planning (Когнитивная психология/ Kognitivnaya psikhologiya, 2002: 315).

The analysis of the topics covered in the online comments made it possible to present the thematic structure of hate speech in a most general way as follows (it should be clarified that they here means a dominated social group and different is used with the negative connotation and implies the right to judge):

1. General.

1.1. I do not like them.

1.2. Some of them are better/worse than the others.

2. Characterization of the social group.

2.1. Their appearance is different.

2.2. Their character and mind are different.

3. Comparison of the group with other social groups.

3.1. They are worse than us.

3.2. They are the same as other 'bad' social groups.

4. Position of the group in the discourse community.

4.1. They threaten our traditional way of life.

4.2. They need to know their place.

It should be underlined that the proposed scheme has a very generalizing character, which means that not all of its components can be "filled" in case of a specific social group and that the border between the identified topics is rather vague in some cases. The "filling" of the components may also vary depending on the targeted group and extralinguistic conditions. We shall consider the proposed scheme in relation to women in the Belarusian discourse community in more detail below. 


\section{Topics and subtopics of sexist hate speech: a Belarusian case}

\subsection{Category "General”}

The "General" category assumes an expression - with a possible direct or indirect insult of a general negative attitude towards a social group or its representatives that the speaker does not explain in any way. This category, as well as the next one - "Characterization of the social group", demonstrates the verbalization of the hostile type of interaction as opposed to the affiliative one (see the classification of interpersonal variables of personality in Leary, 2004: 62-71).

From this perspective, the general proposition "I don't like them" in relation to women can be often found in the citation of proverbs and sayings that depict woman as a destructive force and a cause of man's unhappiness (in general, Russian paremiology demonstrates a tendency to androcentricity, i.e. it reflects the male gaze on the world and the role of man and woman in it - see: Kirilina, 1999), as for example in a comment to the article «Бундесвер начал тестировать форму для беременных женщин-солдат» / 'The Bundeswehr began testing uniforms for pregnant women soldiers' (published on 29/05/2017): Баба на корабле - кбеде / 'A woman on the ship causes disaster' (hereinafter, the authors' spelling and punctuation are preserved, the translation is adapted for clear understanding and stylistically close to the original).

The same negative connotation is expressed in a comment to the article «Похоронил сына, любимую женщину и карьеру. Что стало с любимцем всех женщин Александром Домогаровым» / 'He buried his son, beloved woman and career. What happened to the favourite of all women Alexander Domogarov' (published on 12/07/2019): Водка и бабы сгубили не один талант / 'Vodka and women ruined more than one talent'. The user equates women with a destructive alcoholic drink in their capacity to harm a man.

It should be underlined that in both comments the authors use a colloquial lexeme баба instead of женщина 'woman'. In many cases, the use of this lexeme demonstrates the speaker's disdainful attitude to women even though the comment itself may be neutral, such as one left to the article «"После Абдулова не нужен никто”. Женщины, которых любил секс-символ советского кинематографа / "I don't need anybody after Abdulov." Beloved women of the sex symbol of the Soviet cinema' (published on 29/05/2019) in response to the previous comment expressing doubt in the actor's attractiveness: Андрей,так Тебе и не положено понимать,у баб спроси / 'Andrew, You are not supposed to understand, ask women'.

The second topic "Some of them are better/worse than the others" is not disclosed as such in the comments about women because the main comparison of women is carried out by the Internet users on the basis of their appearance (see the topic "Their appearance is different" in 4.2 below) or following or not following the established norms and rules (see the subtopic "They must behave according to our rules" in 4.4 below). 


\subsection{Category "Characterization of the social group"}

The "Characterization of the social group" category assumes an assessment - mainly negative - of the personal or physical characteristics of the representatives of the social group as such (not involving comparison with other social groups).

In the studied context, the first topic "Their appearance is different" reflects not only stereotypes about women's appearance but also their sexualization and, as a result, comparison. The in-group demonstrates their right to evaluate the members of the outgroup and even judge them. The set of subtopics here is rather wide.

The subtopic "They should be conventionally beautiful" can be illustrated by two comments left to the article «Горячо: сильные женщины в сексуальном календаре для журнала Love» / 'Hot: strong women in the sexual calendar for Love Magazine' (published on 04/12/2017): cтрахотте некае / 'so ugly'; Кошмар. Там что, нормальных баб не осталось... / 'Nightmare. Are there no normal women left...' In both cases, the speakers ascribe to themselves the right to evaluate women and to impose their assessments.

In some cases, this proposition can take a form of "Their appearance is more important than their personality", as for instance in a comment to the article «Шанс найти вторую половину в брачном агентстве у женщин - 40\%, у мужчин - 90\%» / 'Women have a $40 \%$ chance of finding a soul mate in a marriage agency, men - a $90 \%$ chance' (published on 17/02/2017) clearly prioritizes woman's appearance over her character and mind: И разве это плохо? Жена изначально должна быть красивой. А потом - все остальное. С красивой женой не стылно в люди выйти. А то, что страшная тетка такая хорошая домохозяйка, сексуальная партнерша, или готовщчича щуей - на лбу ее не написано. И друзья, знакомые и родители не оценят такой выбор / 'And is that bad? A wife should be beautiful by default. Everything else comes next. If you have a beautiful wife, it's not a shame to go out. And the fact that an ugly woman is such a good housewife, sexual partner, or soup cook is not written on her face. And your friends, acquaintances and parents will not appreciate such a choice'. It should also be mentioned that the user reduces woman's nature to the functions of a housewife taking care of her husband (see the subtopic "They must behave according to our rules" in 4.4 below).

The subtopic "They should be conventionally beautiful" (with its form "Their appearance is more important than their personality") is closely interconnected with the subtopic "Their appearance should attract us sexually" which is in many cases expressed explicitly, as for example in the comment to the article «Какими были самые красивые женщины мира 100 лет назад» / 'What were the most beautiful women in the world 100 years ago like' (published on 06/08/2017): С превеликим удовольствием имею честь предложить вам мадемуазель вдуть / 'With great pleasure I have the honour to offer to slip you mademoiselle a length'. The author of the comment archaizes his speech deliberately, yet the contrasting use of slang makes his representation of women as sexual objects even more vivid.

The tendency to sexualize women also leads to the comparison of their bodies, as for example in a comment to the article «Мужской взгляд: кто стал самой сексуальной женщиной планеты в 2017 году» / 'Man's perspective: who became the sexiest woman 
on the planet in 2017' (published on 11/06/2017): Ү этих хотя бы сиськи какие-никакие есть. А вот у наших “красавии”” с этим беда... / "These [women] at least have some boobs. And our "beauties" have troubles with this'.

From the point of view of the in-group, women's attractiveness is directly related to their age, which finds its reflection in the subtopic "They can be attractive only at a young age". This can be illustrated by a comment to the article «Мнение: "Мужчина, который вступил в противостояние с женщиной, всегда проиграет”» / 'Opinion: The man who entered a confrontation with a woman, will lose anyway' (published on 25/08/2017): и вообще, конкурентное преимущество у основной массы женщин лет до 35 , потом шансов выиграть у мужчины в случае конфликта практически нет ... он то уйдет и найдет ещуе че нибудь, а она кому нужна ... / 'and in general, the majority of women have a competitive advantage up to 35 , then there is practically no chance of winning a man in case of a conflict ... he will leave her and find something else, but who needs her ...'

The second topic "Their character and mind are different" reveals the ideas of the dominant social group about the negative, from their point of view, personal traits of the representatives of the out-group. The intolerant discourse on women reveals the subtopics described below.

The first subtopic covers the idea that all women possess stereotypical traits of character and can be formulated as "They are illogical, deceitful and egoistic" (the range of qualities may vary). This subtopic can be illustrated by comments to the article «Какие мужские качества привлекают женщину? Ответ психолога» / 'What qualities in men attract women? The answer of the psychologist' (published on 10/06/2018): Потомy что женщиины не мыслят рациионально / 'Because women do not think rationally'; У них такая прошивка стоит от природы: возбуждают их наглье плохиши, от них они залетают, рождают ребенка, а потом ищут омегу-содержателя, который будет их и их потомство нянчить, обеспечивать, а сама приэтом будет к тем же плохишам налево бегать (пока омежка вкальвает на работе) / 'They have such firmware by nature: they are aroused by arrogant bad guys, they get knocked up, give birth to a child and then look for an omega-guy who will take care of them and their offsprings and bring money, and she meanwhile will cheat with the same bad guys (while the omega-guy is working hard); Чего только не придумыввают,чтобы не прямо не говорить, что женщин в мужчинах привлекают только деньги / 'They can think of anything not to say directly that the only thing that women find attractive in men is money'.

Sometimes the users create an image of a typical woman, as for example in a comment to the article «Картинка дня: женщина два часа отказывалась поверить, что ошиблась номером» / 'Picture of the day: a woman refused to believe that she got a wrong number for two hours' (published on 27/04/2017): Типичная баба: сама ошиблась, не слушала собеседника, сама себя накрутила, и в итоге конечно он и виноват / 'A typical woman: she made a mistake, did not listen to the interlocutor, got worked up over it, and in the end, of course, he was the one to blame'.

The second subtopic characterizes women in their relations inside the group and takes a form of "They envy each other, gossip, compete and cannot be friends", as for example in a comment to the article «"Не хочу, чтобы наступала на мои грабли”. Зачем 
женщины бесплатно помогают другим женщинам в карьере» / "I do not want them to make my mistakes". Why women help other women for free in their careers' (published on 08/04/2019): Много букв и при этом ни о чем. Никогда женщины не перестанут конкурировать, даже между собой, ибо рядом всегда ходят зависть и сплетни / 'A long-read about nothing. Women will never stop competing, even among themselves, because envy and gossip always go around'.

\subsection{Category "Comparison of the group with other social groups"}

In the "Comparison of the group with other social groups" category the element of juxtaposition - of a targeted out-group and a dominant social group or other out-groups - is crucial: in contrast to the "General" and "Characterization of the social group" categories, this category as well as the next one - "Position of the group in the discourse community" - involves primarily the verbalization of the relations of dominance and submission (and not hostility and affiliation - for more details see: Leary, 2004: 62-71) where the position of the master of the situation is taken by the in-group, and the dominated social groups, including the targeted one, find themselves in the submissive position.

The first topic "They are worse than us" implies a general comparison of the representatives of the out-group with the representatives of the in-group. The speaker can argue their position in various ways, for example, in the case of women the proposition takes a form of "They cannot do what we do (by virtue of their character, mental or physical abilities)". For instance, a user commenting the article «Женщины, готовые на все: истории легендарных летчиц» / 'Women ready for anything: the stories of legendary pilots' (published on 23/04/2018) supports his position with a 'physical' argument: Ну аэробус водить можно.Но на истребители...организм женщины никак не приспособлен к таким перегрузкам.. / 'Well, they can drive an airbus. But fighter jets.... a woman's body is not adapted to such overloads..'

It should be noted that the comments of this group cover a quite standard range of topics such as driving or politics: Хорошо, что клинтон не победила ибо 3 бабы у руля америки, англии и германии привели бы к армагедону / 'It is good that Clinton did not win, for 3 women at the helm of America, England and Germany would lead to Armageddon' (to the article «Женщины против Трампа, сирийские школьники и человекмагнит: фото Рейтер за неделю» / 'Women against Trump, Syrian schoolchildren and a man-magnet: Reuters photos of the week' published on 30/01/2017); Тётеньки сначала едут а патом думают,но не всех думацьь вааще палучаециа.Природа / 'Womеn first drive and then think, but not all of them can think. Nature' (to the article «Под Солигорском женщина на Renault не пропустила MA3: пострадали 6 человек, в том числе 4 ребенка» / 'Near Soligorsk a woman in a Renault did not give the road to MAZ: 6 people were injured, including 4 children' published on 13/06/2019).

The second topic "They are the same as other 'bad' social groups" is not disclosed as such in intolerant discourse on women, but when it comes to women's struggle for their rights they can be placed on the same line with LGBT people, and then the chain can continue (see the subtopic "What they do contradicts our traditions" in 4.4 below). 


\subsection{Category "Position of the group in the discourse community"}

The "Position of the group in the discourse community" category reflects the place of the social group in the system of the prevailing social, economic, cultural, political and legal relations of a particular discourse community. In a very generalizing way, it is possible to single out two topics in this component.

The first topic "They threaten our traditional way of life" is based - as well as all the other topics - on the opposition we - they, yet in this case it is mostly a matter of the values and beliefs of the in-group. In this vein, the speaker might mention the traditional 'good' way of life and accepted 'good' moral, ethical and religious norms of the dominant group ascribing them to the whole discourse community as opposed to the 'bad' lifestyle of the out-group.

Such statements can be aimed at justifying inequality and take the form of "What we do is consistent with our traditions". The speaker's opinion can be supported by examples from the history (either real or religious), as for instance in a comment to the article «Как девушка из Добруша стала иконой стиля и одной из самых влиятельных женщин Дубая» / 'How a girl from Dobrush became a style icon and one of the most influential women in Dubai' (published on 02/01/2018) stating that women are goods to be owned and traded: Женщины в традиционных обществах всегда были собственностью племени или родного отца: принадлежали тому, который вырастил, затратив средства, а потом сам выбрал, кому продать, достойному человеку племени, и взять за неё кальм. В недавнем прошлом отголоски этого сохранялись, когда парню из другой деревни, приехавшему женихаться, местные ребята могли накостылять. А в современном интернациональном мире эмансипированная женщина остаётся таким же товаром для мужчин, но уже продаёт себя сама <...> / In traditional societies, women have always been the property of a tribe or a father: they belonged to the person who raised them, spent the money and then chose to whom to sell them - to a worthy tribe man - and take a bride price for her. In the recent past, the echoes of this remained when a fellow from another village who came to woo [a local girl] could be beaten by the local lads. And in the modern international world, an emancipated woman remains the same goods for men, but she is already selling herself $<\ldots$. ${ }^{\text {'. }}$

The comments of this group also contain the proposition "What they do contradicts our traditions". It is this subtopic that clearly reflects the link between women's empowerment and so-called 'Western/American/European values' that are associated among Belarusian Internet users with promoting the rights of LGBT people. As the latter are often associated in the comments with other 'bad' social groups, such as necrophiles, paedophiles, bestialists and so on, women doing 'male' jobs (see the subtopic "They cannot do what we do" above) can lead, in the commentators' opinions, to the establishment of a different 'bad' social order. This can be illustrated by comments to the two articles devoted to the first ever all-female spacewalk «NASA назвало дату первого в истории выхода двух женщин в открытый космос» / 'NASA announced the date of the first ever two-women spacewalk' (published on 08/03/2019) and «NASA отменило первый в истории 
выход в открытый космос с участием только женщин» / 'NASA cancelled the first ever all-female spacewalk' (published on 26/03/2019): женская пара в открытом космосе? это америка,ребзи! / 'female couple in outer space? this is America, guys!'; Ерунда все это. Яжду, когда выйдет в космос пара негров-геев: это будет вериина развития НACA / 'That's nothing. I'm waiting for a black gay couple to go into space: this will be the pinnacle of NASA's development'; Космос для научных исследований и технического прогресса? Не отвлекайтесь на мелочи! Сперва женщины, затем негры и наконец - трансвеститьл. Мелочи по остаточному принципу / 'Space for scientific research and technological progress? Don't waste your time on trifles! First women, then blacks and finally - transvestites. Trivia by residual principle'.

The second topic "They need to know their place" also finds a broad representation in intolerant discourse on women.

The first subtopic can be formulated as "Their problems are unimportant/exaggerated" and can be illustrated by the comment to the article «Обвиненный в изнасиловании Роналду станет частью акции против насилия над женщинами» / 'Ronaldo, who has been accused of rape, will be part of a campaign raising awareness of violence against women' (published on 23/11/2018): Уже аж тошнит от этих дней против насилия, женских днеи и. Т. Д. Все дамы обиженный, везде их ущземляют, насилуют, домогаются и. Т. Д. Чего же вы тогда вообще связываетесь с этими мужчинами? / 'I am already sick of these days against violence, women's days and so on. All the ladies are offended, they are everywhere restricted, raped, harassed and so on. Then why do you even get involved with these men?'

The second subtopic "Their rights are unfairly placed above ours" is most clearly demonstrated by the communicative tactics of inversion that exposes the dominant group representatives as victims, as for example in the comment to the article «Тина Кароль: “Ощущать свободу - очень важно для современной женщины”» / 'Tina Karol: “То feel freedom is very important for a modern woman" (published on 08/07/2018): Aгa, особенно за счет рабства большей части мужчин, ресурс которых государство перераспределит с кривыми коэффиџиентами 'свободным' женщинам. Хочешь быть свободной - построй дом, вырасти продукты питания, подведи канализацию, зашитти себя сама и потом будешь пиликать про свободу. Эти работы сделают мужчины за несправедливо низкую оплату труда, сливки снимут другие / 'Yeah, especially at the expense of the slavery of most men whose resource will be redistributed by the state with crooked coefficients to 'free' women. If you want to be free - build a house, grow food, connect [the house] to the sewerage system, protect yourself, and then you will prattle about freedom. This work will be done by men for unfairly low wages, and others will skim the cream'.

The third subtopic "They cannot achieve anything without us" is deeply connected with the topic "They are worse than us" (see 4.3 above) and is most frequently found in comments to the articles mentioning women who have succeeded in 'male' spheres or well-off women, for example: Везде наследство. Никто нихрена из них не работал. Грамотный управляюший = состояние унаследованное положила в банк под очень хорочие проценты / 'In each case an inheritance. None of them ever worked a damned 
bit. A competent manager $=$ she deposited the inherited fortune with a high rate of interest'; Все по наследству. У половинь надменные взгляды / 'All by inheritance. Half of them have a haughty look'; Полный фуфел...либо наследство отиа, либо вдова, с нуля никто не поднялся, в чём заслуга / 'Complete bullshit... either the father's inheritance or a widow, none of them rose from scratch, what is the merit'; В чем успех, не угрохали быстро наследство? / 'Where did they succeed, in that they did not quickly waste the inheritance?' (all to the article «Топ-10 самых богатых женщин в мире» / 'Top 10 richest women in the world' published on 26/03/2017).

The last subtopic "They must behave according to our rules" verbalizes stereotypes about 'good' women's behaviour, i.e. that a woman is meant to follow her husband, look after the children, be a good housewife, etc. Women are 'measured' by these criteria under any kind of circumstances, which can be illustrated by a comment to the article «Милиция в Витебске ищет женщину, укравшую все цветы с городской клумбы. Видео» / 'Тhe police in Vitebsk are looking for a woman who stole all the flowers from an urban flower bed. Video' (published on 14/06/2019): А ведь это чья-то мама, вот детям стылно будет увидеть маму в новостях, в таком свете / 'And she is someone's mother, it'll be embarrassing for the children to see their mother in the news in this light'.

Women are also supposed to behave modestly and not demand those rights that men have: Какие права? Свободного секса? Признание таких прав женщины рушит систему брака(семьи). А следовательно приведут к тому что мужчинам женшинь будут нужны для разовых «случек». «21 век-это век Женщины» привел мир к падению нравственности и возобладанию животных начал. Посмотрите в интернете сколько «предложений» женщчин в виде гольх фото... Разложение и мерзость в этом и заключается весь ваш феминизм / 'What rights? Free sex? Recognition of such women's rights destroys the system of marriage (family). Consequently, it will lead to men needing women for one-time "mating". " $21^{\text {st }}$ century is the age of Woman" led the world to the decline of morality and the prevalence of animality. Look how many "offers" of women in the form of naked photos there are on the Internet...' (to the article «Около 50 тысяч женщин погибли за год от насилия в семье» / 'About 50 thousand women died in a year from domestic violence' published on 08/07/2019).

It in is this subtopic that Internet users can call for or approve of violence in a form of "If they don't follow our rules, we can force them". The speaker can justify their views by quoting proverbs and sayings, such as in a comment to the article «Мнение: "Мужчина, который вступил в противостояние с женщиной, всегда проиграет”» / 'Opinion: The man who entered in a confrontation with a woman, will lose anyway' (published on 25/08/2017): Бей бабу молотом, будет баба золотом. Народная мудрость! / '[approx.] If you hit a woman with a hammer, she will be obedient. Folk wisdom!'; or by providing examples of the violent traditions of other communities, as for instance in a comment to the article «Женщину, дочь которой нашли на берегу реки в Бресте мертвой, обвинили в убийстве» / 'The woman whose daughter was found dead on the river bank in Brest was accused of murder' (published on 04/06/2019): Нафиг, на родину. А там надеюсь камнями родня забьёт согласно местным законам / 'Off with her, [let her go back] to the homeland. And there I hope her relatives will stone her according to the local laws'. 


\section{Conclusions and further research}

The analysis of the topical organization of hate speech as form of intolerant discourse made it possible to identify four fundamental categories of the disclosed themes, i.e. (1) general, (2) characterization of the social group, (3) comparison of the group with other social groups and (4) position of the group in the discourse community. Each of these four components of the general topical structure of hate speech contains topics and subtopics that can be presented in the form of propositions expressing value judgments. The range of the themes varies depending on the targeted group and extralinguistic context.

The study of sexist hate speech in the Belarusian discourse community revealed that the topics "Their appearance is different" and "They need to know their place" of the categories "Characterization of the social group" and "Position of the group in the discourse community" respectively cover the widest spectrum of topics, which might be symptomatic of the prevailing attitude to women as sex objects and home-makers. In general, the analysis of the material showed that stereotypical attitude to women is still widely verbalized in online discourse.

Further research prospects are associated with the analysis of the argumentative structures of intolerant discourse, the study of the speaker's communicative strategies and tactics, as well as language means of their implementation.

\section{References}

Assimakopoulos S., Baider F.H., Millar S. (2017), Online hate speech in the European Union: a discourse-analytic perspective, Cham.

Boromisza-Habashi D. (2013), Speaking hatefully: culture, communication, and political action in Hungary, Pennsylvania.

Dijk T.A. van (1987), Communicating racism: Ethnic prejudice in thought and talk, Newbury Park, Beverly Hills, London, New Delhi.

ECRI General Policy Recommendation No. 15 "On Combating Hate Speech" (2016), adopted on December 8, 2015, Strasburg; https://rm.coe.int/ecri-general-policy-recommendation-no-15-on-combating-hate-speech/16808b5b01.

Kirilina A. (1999), Gendernyye stereotipy po dannym yazyka, [in Russian: Кирилина А. Гендерные стереотипы по данным языка // Гендер: лингвистические аспекты] Moscow.

Kognitivnaya psikhologiya (2002), [in Russian: Когнитивная психология / под ред. В.Н. Дружинина, Д.В. Ушакова] Moscow.

Kunitsyna V.N., Kazarinova N.V., Pogol'sha V.M. (2001), Mezhlichnostnoye obshcheniye, [in Russian: Куницына В.Н., Казаринова Н.В., Погольша В.М. Межличностное общение] Saint Petersburg.

Leary T. (2004), Interpersonal diagnosis of personality: a functional theory and methodology for personality evaluation, Eugene. 
Moon R. (2000), The Regulation of Racist Expression. In: Cohen-Almagor R. (ed.) Liberal Democracy and the Limits of Tolerance: Essays in Honor and Memory of Yitzhak Rabin, Ann Arbor, 182-199.

Respublika Belarus v zerkale sociologii (2018), [in Russian: Республика Беларусь в зеркале социологии: сб. материалов социологических исследований / под общ. ред. А.П. Дербина] Minsk.

Shakirova S. (2000), Tolkovaniya gendera, [in Russian: Шакирова С. Толкования гендера // Пол женщины : сб. ст. по гендерным исследованиям] Almaty, 6-32.

Vasilenko E. (2019), Gender-biased hate speech functioning in media: factor-production specifics (a Belarusian case study). In: Oukhvanova I., Senderska J. (eds.) Discourse linguistics and beyond. Vol. 5 : Types of discourses via applied research, Kielce, 119-133.

Vasilenko E.N. (2020), Lingvisticheskiy aspekt pravovogo statusa «yazyka vrazhdy», [in Russian: Василенко Е.Н. Лингвистический аспект правового статуса «языка враждыл» // Вестник Полоцкого государственного университета. Серия А, Гуманитарные науки] Polotsk, 71-76.

\title{
Streszczenie \\ Seksistowska mowa nienawiści: struktura tematyczna dyskursu nietolerancji
}

Celem artykułu jest określenie struktury tematycznej seksistowskiej mowy nienawiści jako formy nietolerancyjnego dyskursu. Seksistowski język wrogości rozpatrywany jest jako rodzaj genderowo uwarunkowanego języka wrogości, na który wpływają te same społeczne, polityczno-prawne i kulturowo-etniczne czynniki, co na język wrogości, oparty na orientacji seksualnej lub identyfikacji genderowej. W artykule zaproponowano całościowe ujęcie struktury tematycznej języka wrogości, przytaczane są przykłady werbalizacji tematów i podtematów seksistowskiego języka wrogości w dyskursie internetowym Białorusi.

Słowa kluczowe: język wrogości, seksistowska mowa nienawiści, genderowo uwarunkowany język wrogości, dyskurs wrogości, dyskurs nietolerancji, dyskurs internetowy, temat

\begin{abstract}
Аннотация
Целью статьи является определение тематической структуры сексистского языка вражды как формы интолерантного дискурса. Сексистский язык вражды рассматривается как вид гендерно обусловленного языка вражды, на который влияют те же социальные, политико-правовые и культурно-этические факторы, что и на язык вражды, основанный на сексуальной ориентации или гендерной идентичности. В статье предлагается тематическая структура языка вражды в целом и приводятся примеры вербализации тем и подтем сексистского языка вражды в интернет-дискурсе Беларуси.
\end{abstract}

Ключевые слова: язык вражды, сексистский язык вражды, гендерно обусловленный язык вражды, дискурс вражды, интолерантный дискурс, интернет-дискурс, тема. 